\title{
A Rare Case of an Osteoid Osteoma of the Rib Treated under Computed Tomography Guidance: A Case Report and Review of the Literature
}

\author{
Sakiko Mizuno ${ }^{a}$ Ukei Anazawa $^{\mathrm{b}}$ Hiraku Hotta $^{\mathrm{b}}$ Naofumi Asano ${ }^{\mathrm{b}}$ \\ Michiro Susa $^{d}$ Jun Miyauchic ${ }^{c}$ Tateru Shiraishi $^{\text {b }}$ \\ ${ }^{a}$ Department of Orthopedic Surgery, Keio University School of Medicine, Tokyo, \\ Departments of ${ }^{b}$ Orthopedic Surgery and ${ }^{C}$ Pathology and Laboratory Medicine, Tokyo \\ Dental College, Ichikawa General Hospital, Chiba, and ${ }^{\mathrm{d}}$ Department of Orthopedic \\ Surgery, National Defense Medical College, Saitama, Japan
}

\section{Key Words}

Osteoid osteoma $\cdot$ Rib $\cdot$ Computed tomography guidance

\begin{abstract}
Osteoid osteoma (OO) usually occurs in the extremities of young adults. The tumor can arise in any part of the skeletal tissue; however, it is rarely found in the rib, with limited reports to date. In this report, we present a rare case of $\mathrm{OO}$ arising in the rib, which was successfully treated under computed tomography guidance with minimal invasiveness. At the final follow-up after 4 years, no local recurrence was observed.

(C) 2015 The Author(s) Published by S. Karger AG, Basel
\end{abstract}

\section{Introduction}

Osteoid osteoma (00) is a benign tumor characterized by a small calcified lesion, usually less than $2 \mathrm{~cm}$ in diameter, with nocturnal pain alleviated by the administration of nonsteroidal anti-inflammatory drugs (NSAIDs). 00 usually affects the long bones and mostly occurs in the first 2 decades of life. 00 arising in the rib is extremely rare, and only 12 cases have been reported in detail to date. Treatment for this tumor is resection of the nidus; however, difficulty in reaching the nidus through normal tissues increases the invasiveness of the surgical procedure. In the reported cases of rib 00s with surgical documentation, the affect-

KARGER125:s $\begin{aligned} & \text { Ukei Anazawa } \\ & \text { Department of Orthopedic Surgery } \\ & \text { Tokyo Dental College, Ichikawa General Hospital } \\ & 5-11-13 \text { Sugano, Ichikawa-shi, Chiba 272-8513 (Japan) } \\ & \text { E-Mail ukei@tc4.so-net.ne.jp }\end{aligned}$


Mizuno et al: : R Rare Case of an Osteoid Osteoma of the Rib Treated under

Computed Tomography Guidance: A Case Report and Review of the Literature

ed ribs were resected in all cases. Here, we present the first case of 00 arising in the rib treated with a computed tomography (CT)-guided procedure without en bloc resection of the affected rib.

\section{Case Report}

A 20-year-old male complained of nocturnal pain in his left anterior chest which had persisted for 2 years. Conservative treatment was performed for a period of 22 months with administration of NSAIDs at a nearby hospital. His symptoms were refractory to medication. Therefore, he was referred to our hospital for further treatment. At the initial visit to our hospital, there was no local tenderness, swelling, or redness. A plain radiograph showed bulging and mild bone sclerosis of the left 8th rib (fig. 1). CT examinations revealed a welldemarcated 5-mm nidus with peripheral bone sclerosis in this area (fig. 2). The bone scintigraphy showed focal uptake of radioisotope only on the left 8th rib. Clinical and radiological findings were compatible with an 00 of the left 8 th rib. Because the patient refused to undergo en bloc rib resection, the operative plan was to perform resection of the nidus under CT guidance. The operative procedure was performed in the CT room under total anesthesia. After identifying the nidus with a marker, a guide pin was inserted by a power drill just adjacent to the edge of the nidus. A 5.0-mm cannulated drill was inserted over the guide pin to remove the nidus. After removing the lesion, the bone specimen which resided in the cannulated drill was sent for histological study. Subsequently, heat ablation by an electrosurgical knife using a standard electrosurgical generator was performed to completely destroy any residual tumors. Each step was confirmed by CT imaging (fig. 3). Histopathological studies showed the characteristic appearance of an 00 with differentiated osteoblasts lining the osteoid and interconnected trabeculae of woven bone (fig. 4). Complete pain relief associated with the nidus resection was achieved from the first postoperative day. The patient was free of pain at the final follow-up after 4 years, and no local recurrence was observed.

\section{Discussion}

OO is a benign osteogenic tumor first reported by Jaffe [1] in 1935. 00s may affect any bone, but more than half of the tumors occur in the long bones of the lower extremities. The frequency of 00s affecting the ribs is extremely low (1 1.4\%), with only 12 reported cases with surgical intervention to date [2-13].

Both conservative and operative techniques have been reported for the treatment of 00. Conservative treatment consists of NSAID administration for a prolonged period of time, which reportedly leads to alleviation of pain in select cases. The common principle for operative treatment of $\mathrm{OO}$ is thorough resection of the nidus, and incomplete resection could lead to local recurrence. A complete resection of the nidus by open surgery may lead to further damage of bone and soft tissues around the lesion, when the affected bone is not subcutaneous or when visual localization of the nidus is technically difficult. Although the ribs are easily accessed, the reported lengths of en bloc resection of the nidus ranged from 5 to $9.5 \mathrm{~cm}$, which is significantly wider than the size of the nidus [4-7]. There are reports of varying degrees of functional impairments due to rib resection.

In 1990, Voto et al. [14] introduced the successful treatment of OOs by percutaneous CTguided resection. Over the years, several percutaneous treatment methods using CT guidance have been introduced: drilling resection, thermocoagulation with radiofrequency, eth- 
Mizuno et al.: A Rare Case of an Osteoid Osteoma of the Rib Treated under Computed Tomography Guidance: A Case Report and Review of the Literature

anol injection, and a combination of these methods. These CT-guided percutaneous procedures are less invasive than conventional resection. However, recurrence rates have been reported to be as high as $10 \sim 20 \%$, and in cases where the nidus is $>10 \mathrm{~mm}$, these procedures have been reported to be more likely to fail [15]. Despite these recurrence rates, a secondary operation either by CT guidance or en bloc resection leads to good results due to the remaining trace left by the primary treatment, enabling minimally invasive en bloc resection. One drawback of CT-guided resection is that a histological diagnosis may be difficult in some cases, because the resected specimens are small in quantity. By using a cannulated drill and careful curettage, we were able to make a histological diagnosis in over $90 \%$ of the cases (data not shown). CT-guided percutaneous treatment should be considered as a first-line therapy for $\mathrm{OO}$ in the majority of cases, except for lesions difficult to access due to the proximity of vital organs, lesions presenting with atypical findings that are difficult to diagnose as 00, and failed primary CT-guided treatments.

\section{Conclusion}

We were able to avoid rib resection without any recurrence of symptoms by the use of a CT-guided resection and heat ablation. In addition, we were able to obtain enough tissue for histological examination by using a $5.0-\mathrm{mm}$ cannulated drill. CT-guided procedures should be considered as a treatment of choice for 00 of the rib in order to minimize the loss of respiratory function.

\section{Statement of Ethics}

The authors have no ethical conflicts to disclose. Informed consent was obtained from the patient for this case report and any accompanying images.

\section{Disclosure Statement}

The authors have no conflicts of interest to declare.

\section{References}

1 Jaffe HL: 'Osteoid-osteoma': a benign osteoblastic tumor composed of osteoid and atypical bone. Arch Surg 1935;31:709-728.

$\rightarrow 2$ Mauer I: Osteoid osteoma of the 12th rib; resection under local anesthesia; a case report. Mil Med 1958;122:194.

3 Kehl DK, Alonso JE, Lovell WW: Scoliosis secondary to an osteoid-osteoma of the rib. A case report. J Bone Joint Surg Am 1983;65:701-703.

4 McGuire MH, Mankin HJ: Osteoid osteoma: an unusual presentation as a rib lesion. A case report. Orthopedics 1984;7:305-307.

5 Mehdian H, Summers B, Eisenstein S: Painful scoliosis secondary to an osteoid osteoma of the rib. Clin Orthop Relat Res 1988;230:273-276.

-6 Veluvolu P, Winkler T, Sajjad SM, Leer RA, Fontanini SM: Osteoid osteoma involving body of right rib. Preoperative localization and postoperative confirmation. Clin Nucl Med 1992;17:895-896.

7 Deng Z, Ding Y, Hao L, et al: Osteoid osteoma of the rib: a report of two cases. Oncol Lett 2015;9:1857-1860.

8 Lynch MC, Dorgan JC: Osteoid osteoma of a rib as a cause of scoliosis. A case report. Spine 1986;11:480-482.

-9 Nelson MC, Brower AC, Ragsdale BD: Case report 448. Osteoid osteoma of left 6th rib with inflammatory reaction in the adjacent pleura and hyperostosis of the adjacent ribs. Skeletal Radiol 1987;16:601-603. 


\section{Case Reports in Oncology}

\begin{tabular}{l|l}
\hline Case Rep Oncol 2015;8:509-514 \\
\hline DOI: $10.1159 / 000441835$ & $\begin{array}{l}\text { (c) 2015 The Author(s). Published by S. Karger AG, Basel } \\
\text { www.karger.com/cro }\end{array}$ \\
\hline
\end{tabular}

Mizuno et al.: A Rare Case of an Osteoid Osteoma of the Rib Treated under Computed Tomography Guidance: A Case Report and Review of the Literature

10 Kozlowski D, Campbell J, Morris L, Sprague P, Taccone A, Beluffi G, Marcinski A, Porta F, Stevens M: Primary rib tumors in children (report of 27 cases with short literature review). Australas Radiol 1989;33:210-222. Cossetto D, Cummine J: Rapidly growing twelfth rib osteoid osteoma. Aust NZ J Surg 1991;61:862-864.

$\checkmark 12$ Hoeffel JC, Lascombes P, Delgoffe C, Aymard B, Galloy MA: Osteoid osteoma of the rib: a case report. J Pediatr Surg 1993;28:738-740.

13 McDermott MB, Kyriakos M, McEnery K: Painless osteoid osteoma of the rib in an adult. A case report and a review of the literature. Cancer 1996;77:1442-1449.

14 Voto SJ, Cook AJ, Weiner DS, Ewing JW, Arrington LE: Treatment of osteoid osteoma by computed tomography guided excision in the pediatric patient. J Pediatr Orthop 1990;10:510-513.

15 Lindner NJ, Ozaki T, Roedl R, Gosheger G, Winkelmann W, Wörtler K: Percutaneous radiofrequency ablation in osteoid osteoma. J Bone Joint Surg Br 2001;83:391-396.

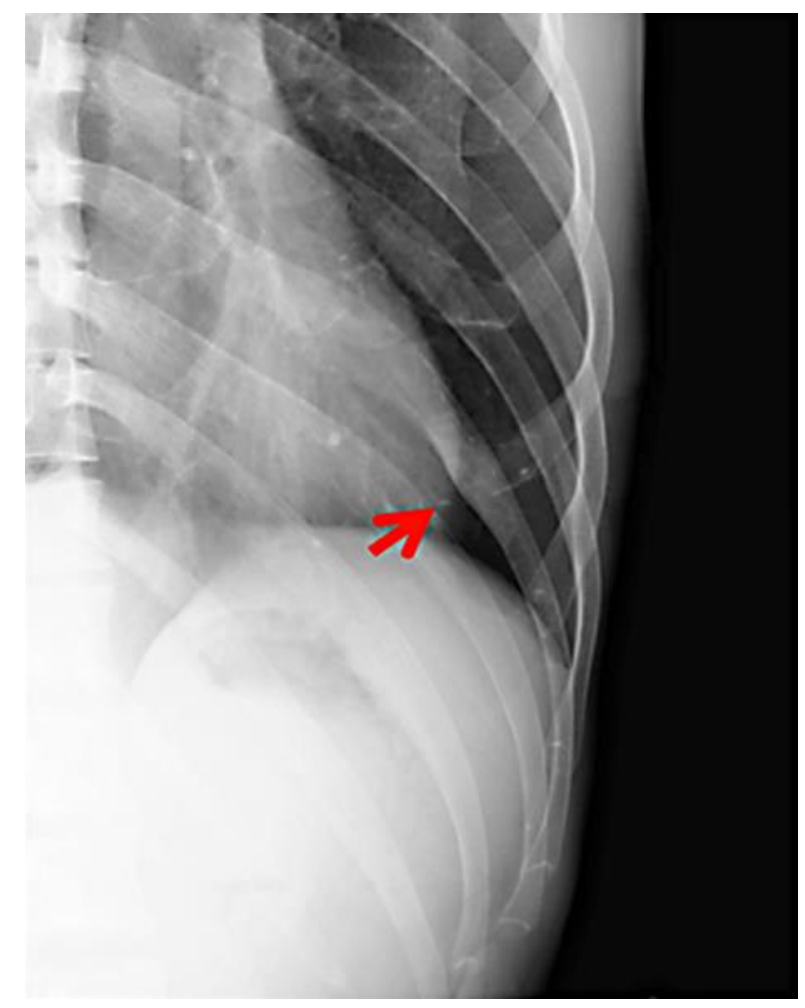

Fig. 1. Radiograph of the rib at the initial presentation. Bulging and mild sclerosis can be seen in the left 8th rib (arrow). 


\section{Case Reports in Oncology}

\begin{tabular}{l|l}
\hline Case Rep Oncol 2015;8:509-514 \\
\hline DOI: 10.1159/000441835 & $\begin{array}{l}\text { (c) 2015 The Author(s). Published by S. Karger AG, Basel } \\
\text { www.karger.com/cro }\end{array}$ \\
\hline
\end{tabular}

Mizuno et al.: A Rare Case of an Osteoid Osteoma of the Rib Treated under

Computed Tomography Guidance: A Case Report and Review of the Literature
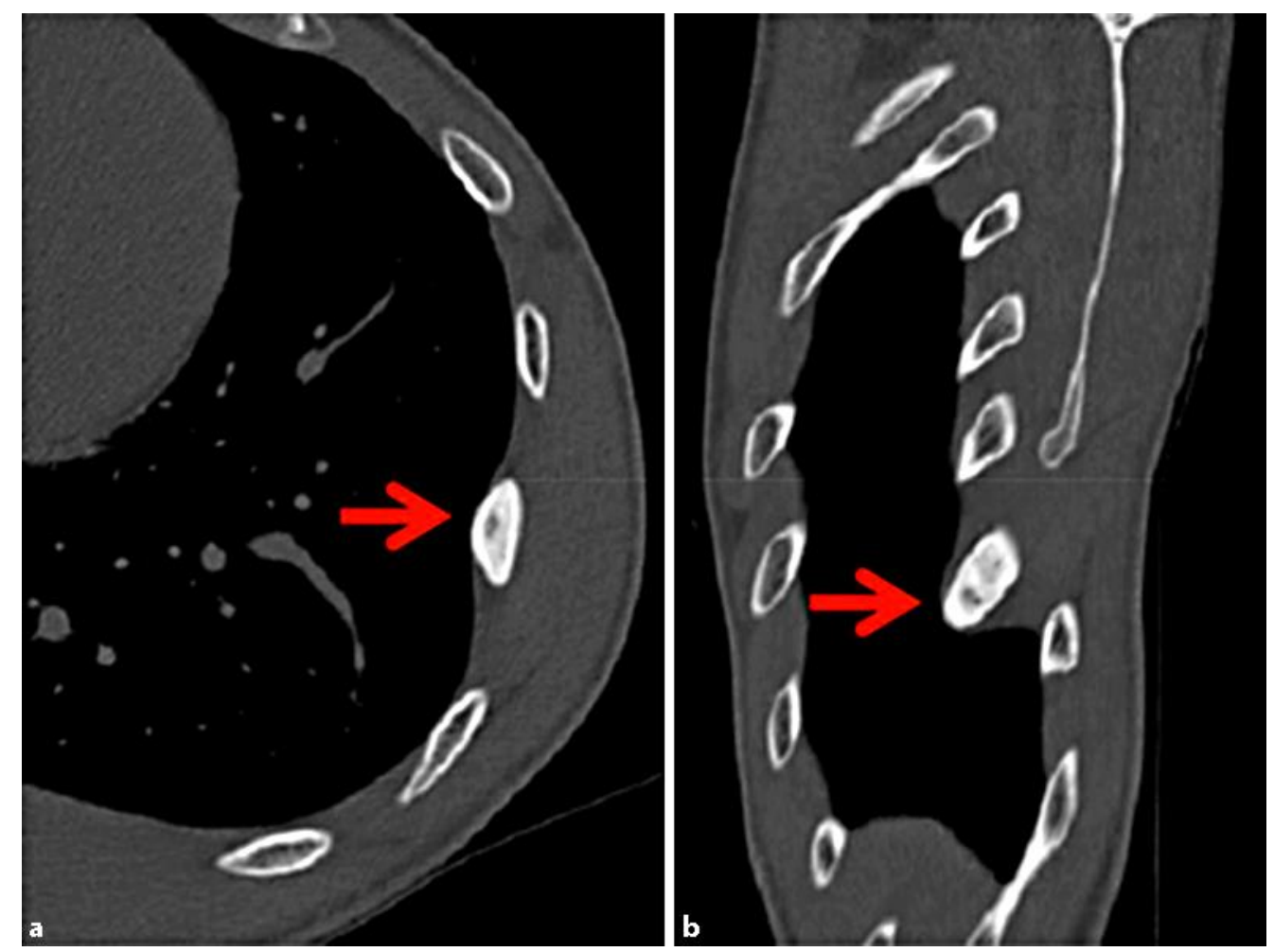

Fig. 2. Preoperative CT examination. Axial view (a) and sagittal view (b). An osteolytic lesion surrounded by bone sclerosis (arrow) can be observed in the left 8 th rib without any periosteal reaction.
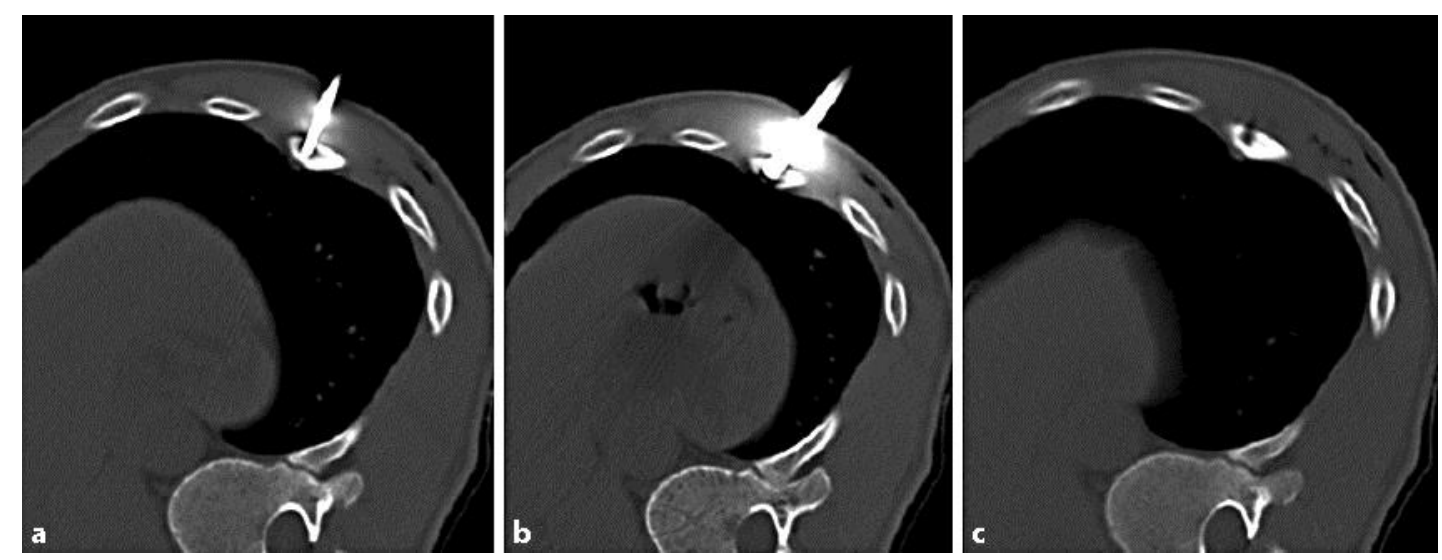

Fig. 3. Intraoperative findings. a A guidewire has been inserted into the nidus under CT guidance. b Tumor resection by a $5.0-\mathrm{mm}$ cannulated drill over the guidewire. c A postoperative CT shows the successful resection of the nidus. 


\section{Case Reports in Oncology}

\begin{tabular}{l|l}
\hline Case Rep Oncol 2015;8:509-514 \\
\hline DOI: $10.1159 / 000441835$ & $\begin{array}{l}\text { (c) 2015 The Author(s). Published by S. Karger AG, Basel } \\
\text { www.karger.com/cro }\end{array}$ \\
\hline
\end{tabular}

Mizuno et al.: A Rare Case of an Osteoid Osteoma of the Rib Treated under Computed Tomography Guidance: A Case Report and Review of the Literature

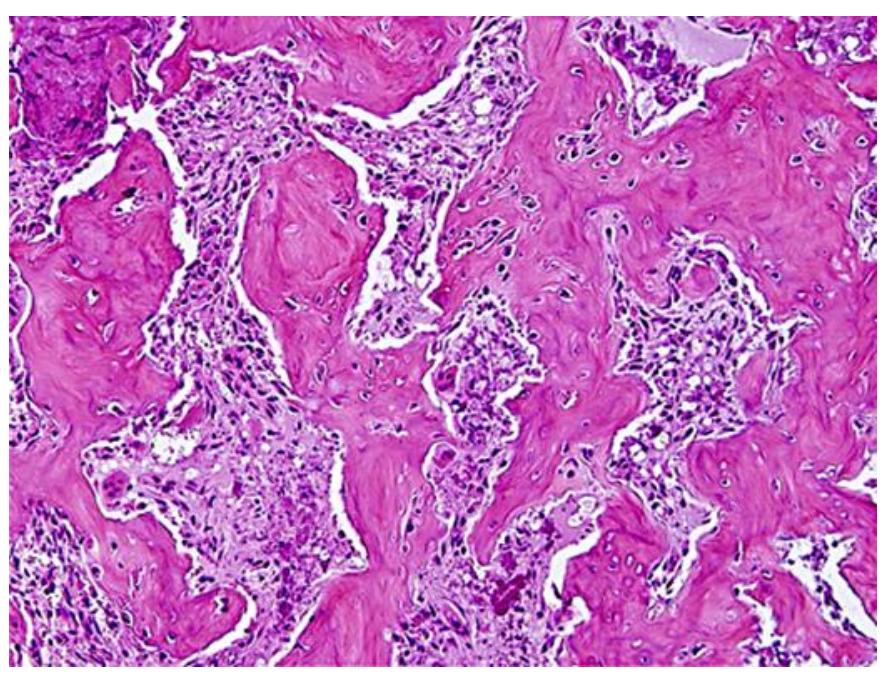

Fig. 4. Histopathological findings demonstrate random reticular osteoid formation within a fibrovascular stroma consistent with 00. 